\title{
Clonal analysis of three morphologically distinct lymphomas occurring in the same patient
}

\author{
C McCormick, E Philp, J Mansi, N Livni, K McCarthy
}

\begin{abstract}
Aims-To determine whether three morphologically distinct lymphomas (mucosa associated lymphoid tissue (MALT) lymphoma, monocytoid B cell lymphoma, and large cell anaplastic lymphoma), which occurred in the same patient, were in fact three morphological variants of the same lymphoproliferative process.

Methods-Previously described methods of clonal analysis using the polymerase chain reaction (PCR) were used to determine the pattern of rearrangements of the immunoglobulin heavy chain gene and the $T$ cell receptor $\beta$ and $T$ cell receptor $\gamma$ chain genes in the three lymphomas. Results-All three morphological entities had identical patterns of gene rearrangements.

Conclusions-This finding confirms the association between MALT lymphoma and monocytoid $B$ cell lymphoma, and also provides evidence that large cell anaplastic lymphoma may not only arise de novo but may also be an end stage morphological picture in lymphoma progression.
\end{abstract}

(F Clin Pathol 1994;47:1038-1042)

The occurrence in one patient of more than one morphologically distinct lymphoid neoplasm, either concurrently or sequentially, is well recognised. Many cases represent blast cell transformation occurring in a low grade lymphoma and resulting in a more aggressive or high grade tumour. This phenomenon was noted in $40 \%$ of cases of centroblastic/centrocytic lymphomas in a necropsy study undertaken by Lennert. ${ }^{1}$ Transformation is usually to centroblastic lymphoma, although less frequently the high grade lymphoma is composed predominantly of bizarre, anaplastic cells, and very occasionally transformation to a B immunoblastic lymphoma is seen. ${ }^{2}$ Another well recognised entity is diffuse large cell lymphoma arising in patients with a previous history of chronic lymphocytic leukaemia (CLL). This phenomenon is known as Richter's syndrome. ${ }^{34}$ The reported incidence in CLL is $3-10 \%$.

In 1988 Cogliatti et al described a series of patients with monocytoid B cell lymphoma (MBCL). ${ }^{5}$ A subset of their study group (33\%) also had concomitant low grade B cell lymphoma of mucosa associated lymphoid tissue (MALT). ${ }^{5}$ Two of these cases later developed into unspecified high grade lymphomas. Investigations to determine clonality were not undertaken in this series, but recent work on both Richter's syndrome ${ }^{6}$ and on blast cell transformation of centrocytic/centroblastic lymphoma, ${ }^{7}$ using restriction enzyme analysis (Southern blotting) ${ }^{8}$ to detect immunoglobulin gene rearrangements, has shown a clonal relation between the initial low grade neoplasm and the subsequent high grade lymphoma.

Here, we report a case of a 75 year old woman who developed three morphologically distinct malignant lymphomas over an 11 year period. In spite of the range of histological appearances shown by these tumours (a primary gastric lymphoma, a low grade rectal MBCL, and most recently a $\mathrm{Ki}-1$ positive large cell anaplastic lymphoma (LCAL) in her cervical nodes), gene rearrangement studies using PCR were highly suggestive that all three lesions were the same clone.

\section{Case report}

A 63 year old woman, presented in 1979 with a 10 month history of epigastric pain and weight loss. Endoscopy revealed a $5 \mathrm{~cm}$ in diameter ulcer on the lesser curve. After biopsy, a radical gastrectomy was performed. Histological examination showed a diffuse high grade gastric lymphoma. She received adjuvant chemotherapy and subsequently abdominal radiotherapy.

She remained well until October 1990 when she presented again, this time with a short history of anorexia and general malaise. A rectal polyp was discovered, which on histology, was shown to be a monocytoid B cell lymphoma. Coincidentally she developed rapidly enlarging right upper cervical and left supraclavicular lymphadenopathy. A biopsy specimen of the supraclavicular node revealed a large cell anaplastic lymphoma. A computed tomography scan also revealed lymphadenopathy in the region of the coeliac axis, but a bone marrow examination was normal. From January 1991 to August 1991 she received seven courses of combination chemotherapy. She responded extremely well to treatment, but she was left with a small mass in the cervical chain that was cytologically negative for malignant cells. This node continued to regress in size during follow up.

\section{Pathological findings}

Gastric lesion (tumour 1); March 1979

A total gastrectomy specimen with attached greater omentum, spleen, and part of the pancreas was received fixed in formalin. Opening the stomach revealed a superficially ulcerated
Histopathology, St George's

Hospital, Blackshaw Road,

London SW17 0QT

Accepted for publication

19 April 1994 


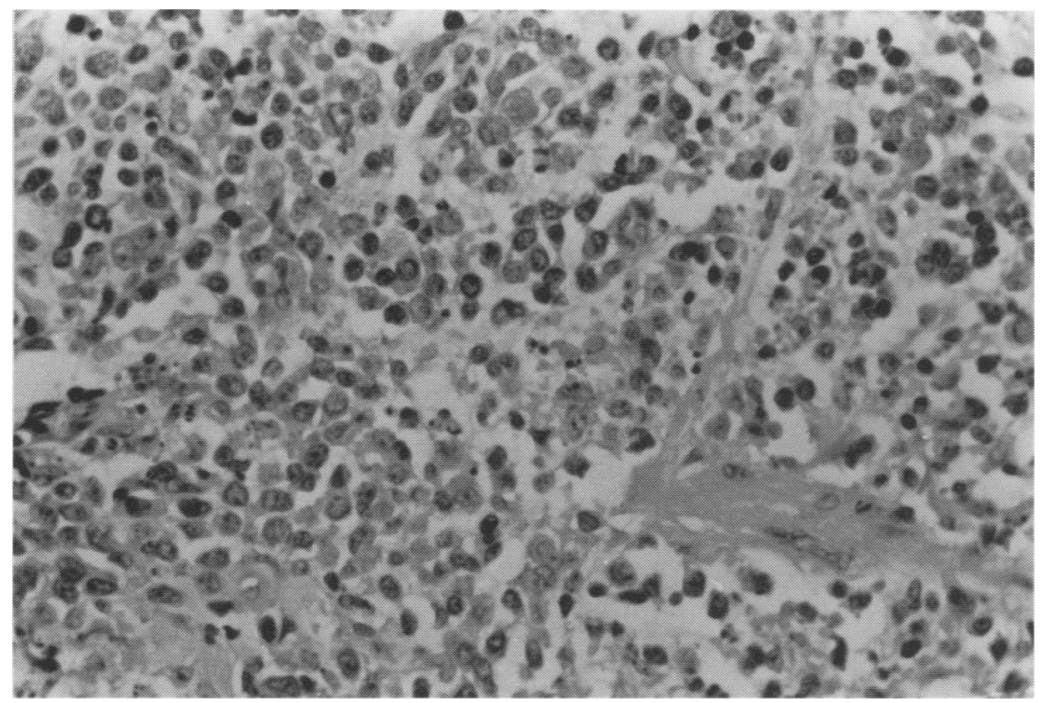

Figure 1 High grade gastric lymphoma displaying loosely cohesive sheets of large cells with a coarsely granular chromatin pattern and frequent mitoses.

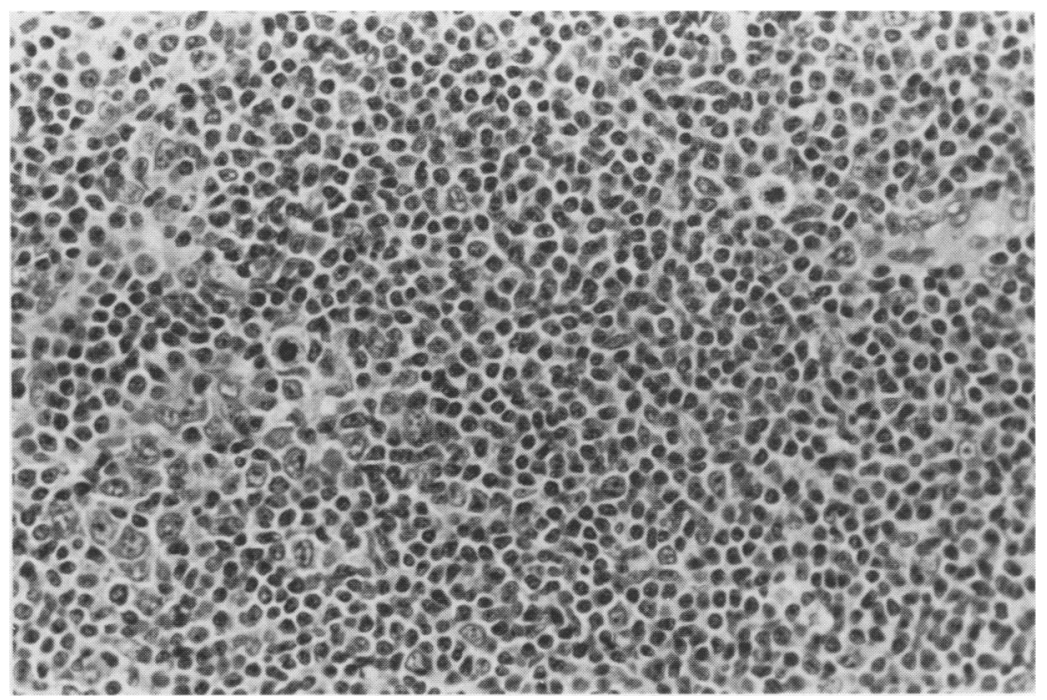

Figure 2 Colonic polyp containing a mixture of cell types, including an important component of uniform larger neoplastic monocytoid cells with pale cytoplasm and indented nuclei.

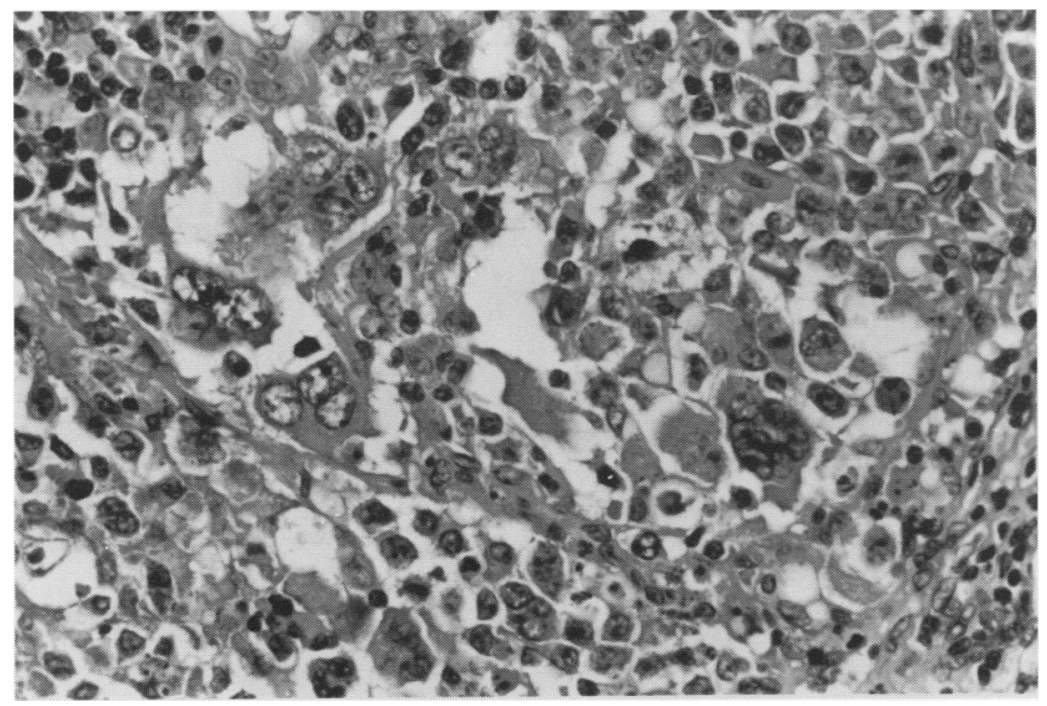

Figure 3 Cervical lymph node replaced by large cell anaplastic lymphoma. Numerous bizarre cells, including multinuclear forms, are present. thickened area $70 \mathrm{~mm} \times 30 \mathrm{~mm}$ on the greater curve. Twelve lymph nodes were dissected off the specimen. Histological examination (fig 1) showed a diffuse high grade primary gastric lymphoma. The central part of the tumour was formed by solid masses of large lymphoid cells with coarsely granular nuclear chromatin and a high mitotic rate. Numerous reactive looking germinal follicles in the adjacent lymphoid tissue suggested transformation from a pre-existing low grade MALT lymphoma. The neoplastic cells infiltrated downwards into, but not through, the muscularis propria. One of the 12 lymph nodes was also focally affected, with tumour cells growing in a perifollicular, or mantle-zone pattern. No Helicobacter pylori organisms were identified in the sections.

\section{Colonic lesion (tumour 2); October 1990}

An intact pedunculated polyp measuring 20 $\mathrm{mm}$ in maximal cross-sectional dimension and $13 \mathrm{~mm}$ in height was received in formalin. The polyp had a homogeneous, firm, creamcoloured cut face. Haematoxylin and eosin stained sections showed a lymphoproliferative mass covered by somewhat attenuated, but otherwise normal, colonic mucosa. The lymphoid tissue had a vaguely nodular pattern and was composed of mixed large and small lymphoid cells interspersed with prominent aggregates of granular macrophages and scattered polymorphs and eosinophils. High power examination of the lymphoid nodules revealed small reaction centres, numerous plasma cells and, in places, an infiltrate of uniform neoplastic monocytoid cells with abundant pale cytoplasm and large, slightly indented, or reniform nuclei (fig 2). This infiltrate focally impinged on the reaction centres. These morphological features are those of a monocytoid B cell lymphoma.

Cervical lymph node (tumour 3); December 1990 Part of a lymph node measuring $20 \times 18 \times 5$ $\mathrm{mm}$ was received in formalin. The node had a slightly nodular cut face. Sections showed effacement of nodal architecture by a diffuse infiltrate of large lymphoid cells with vesicular nuclei, prominent nucleoli, and abundant cytoplasm (fig 3). A smaller population of multinucleate and bizarre forms was also present. Mitotic rate was high and focal necrosis was noted. The morphological appearances were consistent with large cell anaplastic lymphoma.

Immunohistochemical staining was undertaken on all three lesions using a panel of antibodies (table 1).

Table 1 Panel of antibodies used

\begin{tabular}{lll}
\hline Antibody & Source & Action \\
\hline UCHL1 (CD45RO) & Dakopatts a/s & $\begin{array}{l}\text { Pan-T cell marker; } \\
\text { also marks a subset of } \\
\text { B cells }\end{array}$ \\
$\begin{array}{ll}\text { L26 (CD20) } \\
\text { BerH2 (CD30) }\end{array}$ & $\begin{array}{l}\text { Dakopatts a/s } \\
\text { Dakopatts a/s }\end{array}$ & $\begin{array}{l}\text { Pan B cell marker } \\
\text { Detects the Ki-1 } \\
\text { antigen in activated } \\
\text { lymphoid cells }\end{array}$ \\
Mac387 & $\begin{array}{l}\text { Dakopatts a/s } \\
\text { Dakopatts a/s }\end{array}$ & $\begin{array}{l}\text { Hartiocytic cell marker } \\
\text { Marker of epithelial } \\
\text { cells and some subsets } \\
\text { of lymphoid cells }\end{array}$ \\
\hline
\end{tabular}


Table 2 Results of immunohistochemical staining

\begin{tabular}{llllll}
\hline & UCHL1 & L26 & BerH2 & Mac387 & EMA \\
\hline Gastric lymphoma & - & + & - & ND & - \\
Colonic polyp & - & + & - & - & - \\
Cervical node & - & + & + & ND & -
\end{tabular}

+ Strong staining of tumour cells; - negative staining of tumour cells, possibly with positive staining of reactive lymphoid cells; ND, not done. Unfortunately, no fresh or frozen tissue was available, thus limiting the immunohistochemical profile.
The results of immunostaining are shown in table 2 .

\section{CLONAL ANALYSIS}

Sections $(25 \mu \mathrm{m})$ were cut from tissue blocks on which previous microscopy had shown considerable numbers of neoplastic cells. These were then dewaxed in xylene and the xylene removed by washing twice in $100 \%$ ethanol. DNA was then extracted by proteolysis and phenol-chloroform extraction as described before. ${ }^{9}$

PCR analysis of the immunoglobulin heavy chain $(\operatorname{IgH}), \mathrm{T}$ cell receptor $\beta$ (TCR $\beta)$ and T cell receptor $\gamma$ (TCR $\gamma$ ) genes was then undertaken using reaction conditions, dimers, and temperatures, as described before. ${ }^{10-12}$ The reactions were run out in $10 \%$ polyacrylamide gel and viewed under ultraviolet light.

Using this protocol, monoclonal proliferations generate discrete bands whereas polyclonal (reactive) proliferations and nonlymphoid proliferations generate a diffuse "smear" on the gel. The results showed that all three tumours showed identically sized partial rearrangements of TCR $\beta$ (65 and 90 base pairs) and of TCR $\gamma$ (90 base pairs). No rearrangements of the IgH gene were found (fig 4).

\section{Discussion}

The occurrence of three morphologically different lymphomas in one patient over an extended period of time, as described in our case report, is unusual. There are, however, numerous cases in which two morphologically different non-Hodgkin's lymphomas (NHL) or even NHL and Hodgkin's disease occurred in the same patient. ${ }^{13}$ Although this phenomenon hinted at a pathogenetic association, it was seldom possible to demonstrate monoclonality until the advent of molecular genetic techniques. We undertook clonal analysis in this case to investigate whether all three tumours represented progressively less well differentiated morphological manifestations of the same lesion.

The initial gastric lymphoma presenting in 1979 displayed features to suggest that its origin was in a pre-existing low grade MALT lymphoma. Low grade lymphomas of MALT are characterised by the presence of reactive $B$ cell follicles surrounded by neoplastic centrocyte-like cells. These neoplastic cells infiltrate diffusely, and also selectively invade epithelial structures to produce characteristic lymphoepithelial lesions. ${ }^{14}$ The presence of numerous reactive-looking germinal centres at the periphery of the gastric lymphoma and the phenomenon of follicular colonisation ${ }^{15}$ identified in our case point towards the probability of a pre-existing low grade MALT lymphoma. ${ }^{16}$ The gastric lymphoma could therefore reasonably have been expected to behave in a fairly indolent clinical manner.

The MBCL occurring 10 years later is representative of a tumour type which, although related to MALT lymphoma, ${ }^{5}$ is not imbued with the same tendency to "home" into sites with MALT. A lymphoma composed of monotypic monocytoid B cells was first described by McGinn et al in $1985^{17}$ and the term MBCL was coined in 1986 by Sheibani et al. ${ }^{18}$ The co-existence of an MBCL with a concomitant MALT lymphoma is a recognised association ${ }^{5}$ but the clinical course of the former is somewhat more aggressive.

The $\mathrm{Ki}-1$ positive LCAL was the final and least well differentiated morphological manifestation of the neoplasm. Most $\mathrm{Ki}-1$ positive LCALs in the series reported by Chott et al in 1990 exhibited either $\mathrm{T}$ cell lineage $(68 \%)$ or displayed no markers at all (22\%). ${ }^{19}$ However, the less common B cell variants $(10 \%)$ displayed an equally aggressive clinical course with an overall median survival time of only 13 months from the time of diagnosis. Similar
Figure 4 The results of clonal analysis by PCR of the three tumours are shown. The figures at the top refer to the tumours. The symbols at the bottom refer to the antigen receptor genes $(\beta T C R \beta ; \gamma-T C R \gamma$; $h$-IgH). The figures refer to band sizes in base pairs. In all three tumours bands are clearly visible at 65 and 90 base pairs $(\beta)$ and 90 base pairs $(\gamma)$

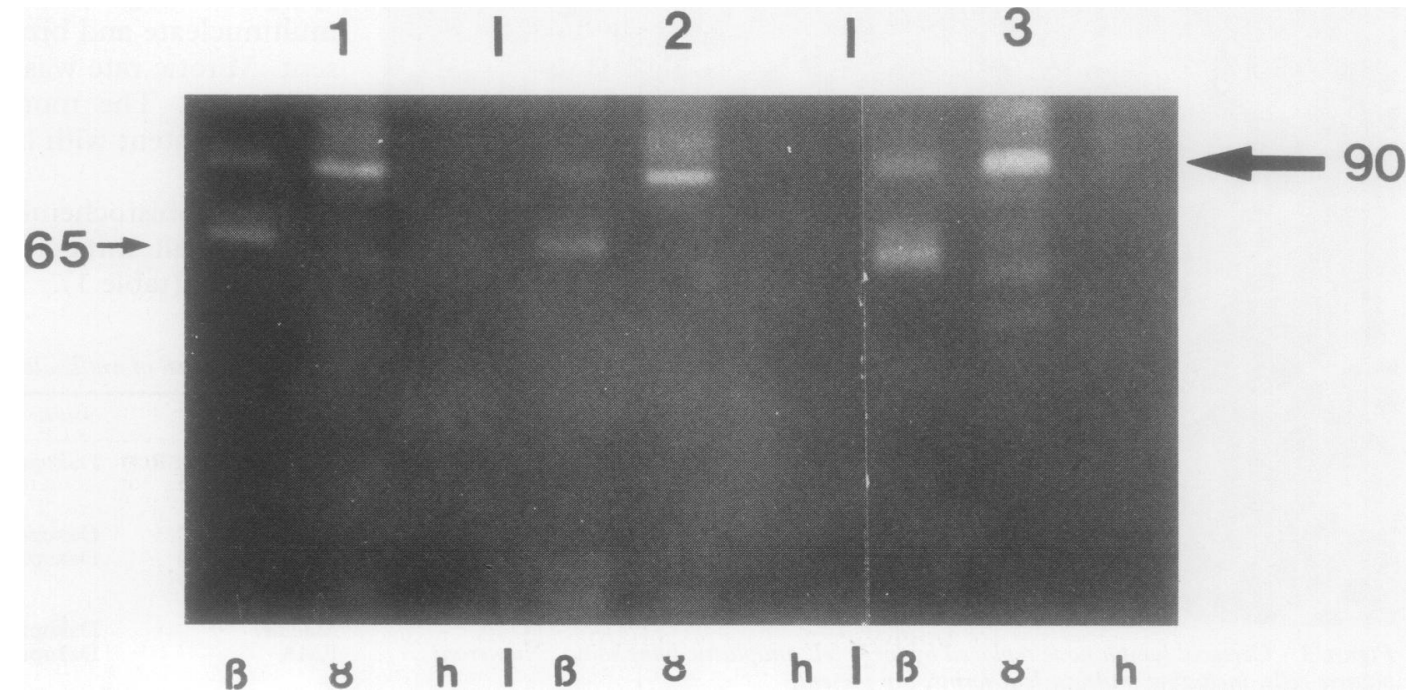


patterns of immunoreactivity to those demonstrated by Chott have also been shown in LCAL by other workers. ${ }^{2021}$

Negative immunohistochemical staining on paraffin wax sections for epithelial membrane antigen (EMA) (as we found in our case) was reported in $42 \%$ of the cases considered by Chott et $a l^{19}$ and highlights the point that EMA positivity is not a prerequisite for diagnosis of LCAL. Notably, only about half of all $\mathrm{Ki}-1$ positive LCALs are positive for leucocyte common antigen (C.CA) on paraffin wax sections; and the phenotype LCA negative/ EMA positive was found in $30 \%$ of the cases reported by Chott et al. This phenotype may lead to diagnostic confusion between LCAL and anaplastic carcinoma in some circumstances.

Recent studies by Bitter et $a l^{22}$ and by other workers $^{23}$ have suggested that there are two morphological groups of $\mathrm{Ki}-1$ positive lymphomas and that the presence of a unique chromosomal abnormality, $t(2 ; 5)(\mathrm{p} 23 ; \mathrm{q} 35)$ defines the subset of $\mathrm{Ki}-1$ positive lymphomas displaying classic anaplastic morphology on haematoxylin and eosin staining, as opposed to the second group which displayed morphological features of high grade non-Hodgkin's lymphoma without specific unifying features. In 1989 Chan et al also recognised two morphologically distinct variants of anaplastic $\mathrm{Ki}-1$ positive large cell lymphoma but did not relate their observations to the karyotype of the tumour cells. ${ }^{21}$

Most cases of $\mathrm{Ki}-1$ positive LCAL develop de novo (primary type), ${ }^{19-21}$ but a small number arise secondary to other types of lymphoma $^{212425}$ and may represent the end point of a dedifferentiating tumour sequence. Mycosis fungoides, lymphoepithelioid lymphoma, and angioimmunoblastic-type $T$ cell lymphoma have all shown this transformation in their later stages.

It is interesting to speculate that $\mathrm{Ki}-1$ positive LCAL arising secondarily may represent a subset of the group of LCALs without the $t(2 ; 5)(p 23 ; q 35)$ translocation. This suggestion would be supported by the dual observations: firstly, that the prognosis of secondary LCALs is worse than that of primary $\mathrm{LCAL}^{25}$; and secondly, that $\mathrm{Ki}-1$ positive lymphomas lacking the specific translocation have a worse prognosis than those with it. ${ }^{22}$

To identify the rearrangements, we used the polymerase chain reaction technique (PCR). As only formalin fixed, paraffin wax embedded tissue was available for investigation, this study would not have been possible using the more conventional methodology of restriction enzyme analysis (such as Southern blotting). PCR is particularly suitable when analysing blocked archival material. ${ }^{26}$

It may seem somewhat paradoxical, at first sight, that all three B cell tumours shared only $\mathrm{T}$ cell gene rearrangements. However, both partial TCR $\beta$ gene and TCR $\gamma$ gene rearrangements are often found in B cell neoplasms. ${ }^{27}$ The lack of a demonstrable clonal immunoglobulin heavy chain (IgH) gene rearrangement is also acceptable because of the significant false negative rates for PCR with IgH rearrangements. ${ }^{9}$ In this particular case all three tumours failed to show an IgH rearrangement, thereby providing additional supportive circumstantial evidence that they were in fact the same clone. The fact that TCR genes are rearranged in a $B$ cell lesion highlights the importance of looking for multiple rearrangements in all lymphoid tumours.

In the case reported here we cannot conclusively prove clonality between the three tumours as to do so would require sequencing of the amplified rearrangements. This technique is unsatisfactory when undertaken on PCR products produced using degenerate primers. However, as the rearrangements demonstrated are identical in all three cases, the probability that they are the same tumour is extremely high.

We believe that PCR techniques, as applied here, demonstrate that PCR will continue to be a valuable tool in the further understanding of the pathogenesis of lymphoid neoplasms, without the inherent technical difficulties presented by restriction enzyme analyses. The case also demonstrates the importance of looking for multiple antigen receptor gene rearrangements to reduce the risk of false negative results.

We feel that the demonstration of probable monoclonality in this unusual case with three histologically distinct appearances is relevant to other cases of synchronous or metachronous lymphoid malignancies, and that it illuminates the complex relation between the biology and morphology of lymphomas. The case also adds supporting evidence to the hypothesis that LCAL is a heterogeneous group of neoplasms, which may arise not only de novo, but also as the end stage in the progression of a lymphoproliferative disorder.

We thank Dr A J Stansfeld for histological review of the tumours, Dr I Jeffrey for her support and advice, and Mrs V Emmons for preparation of the manuscript.

1 Lennert K. Histopathology of non-Hodgkins' lymphomas (based on the Kiel classification). Berlin: Springer-Verlag, 1981:70-1.

2 Stansfeld AG. Lymph node biopsy interpretation. 2nd edn Edinburgh: Churchill-Livingstone, 1991:259-60.

3 Armitage JO, Dick FR, Corder M. Diffuse histiocytic lymphoma complicating chronic lymphocytic leukaemia. phoma complicating

4 Foukar K, Rydell RE. Richter's syndrome in chronic lymphocytic leukaemia. Cancer 1980;46:118-34.

5 Cogliatti SB, Lennert $\mathrm{K}$, Hansman ML, Zwingers TL. Monocytoid B-cell lymphoma: clinical and prognostic features of 21 patients. $\mathcal{f}$ Clin Pathol 1990;43:619-25.

6 Bayliss KM, Kueck BD, Hanson CA, Matthaeus WG, Almagro UA. Richter's syndrome presenting as primary central nervous system lymphoma. Transformation of an identical clone. Am ₹ Clin Pathol 1990;93:117-23.

7 Zelenetz AD, Chen TT, Levy R. Histologic transformation of follicular lymphoma to diffuse lymphoma represents tumour progression by a single malignant B-cell. f Exp Med 1991;173:197-207.

8 Arnold A, Cossman J, Bakhshi A, Jaffe ES, Waldmann TA, Korsmeyer SJ. Immunoglobulin gene rearrangements as unique clonal markers in human lymphoid neoments as unique clonal markers in human

9 Sambrook J, Fritsch EF, Maniatis T. Molecular cloning. A laboratory manual. 2nd Edn. Cold Spring Harbor: Cold

10 McCarthy KP, Sloane JP, Wiedemann LM. Rapid method for distinguishing clonal from polyclonal B-cell populations in surgical biopsy specimens. $f$ Clin Patho 1990;43:429-32.

11 McCarthy KP, Sloane JP, Kabarowski JHS, Matutes E Wiedemann LM. The rapid detection of clonal T-cel proliferations in patients with lymphoproliferative disorders. Am $\mathcal{F}$ Pathol 1991;138:821-8. 
12 McCarthy KP, Sloane JP, Kabarowski JHS, Matutes E, Wiedemann LM. A simplified method of detection of clonal rearrangements of the T-cell receptor-gamma clonal rearrangements of the T-cell recepto
chain gene. Diagn Mol Pathol 1991;1:173-9.

$13 \mathrm{Kim} \mathrm{H,Hendrickson} \mathrm{MR,} \mathrm{Dorfmann} \mathrm{RF.} \mathrm{Composite}$ lymphoma. Cancer 1977;40:959-76.

14 Isaacson PG, Spencer J. Malignant lymphoma of mucosaassociated lymphoid disease. Histopathology 1989;11 445-62.

15 Isaacson PG, Wotherspoon AC, Diss T, Pan L. Follicular colonization in B-cell lymphoma of mucosa-associated lymphoid tissue. Am $\mathcal{F}$ Surg Pathol 1991;15:819-28.

16 Chan JKC, $\mathrm{Ng} \mathrm{CS}$, Isaacson PG. Relationship between high grade lymphoma and low grade B-cell mucosaassociated lymphoid tissue lymphoma. Am $₹$ Pathol 1990;136:1153-64.

17 McGinn DI, Cousar JB, List AF, Click AD, Collins AF Report of an unusual interfollicular lymphoma arising from sinusid B-lymphites. Lab Invest 1985;52:42A

18 Sheibani K, Sohn CC, Burke JS, Winberg CD, Wu AM Rapporport H. Monocytoid B-cell lymphoma: A novel B-cell neoplasm. Am f Pathol 1986;124:310-8.

19 Chott A, Kaserer K, Augustin I, Veseley M, Heinz R Oehlinger W, et al. Am $¥$ Surg Pathol 1990;14:439-48.

20 Agnarsson BA, Kadin ME. Ki-1-positive large cell lymphoma: a morphological and immunological study of 19 cases. Am $\mathcal{F}$ Surg Pathol 1988;12:264-74.

21 Chan JKC, Ng CS, Hui PK, Leung TW, Lo ESF, Lau WH, et al. Anaplastic large cell $\mathrm{Ki}-1$ lymphoma. Delineation of two morphological types. Histopathology
1989;15:11-34

22 Bitter MA, Franklin WA, Larson RA, McKeithan TW, Rubin CM, Le Beau MM, et al. Morphology in Ki-1positive (CD30) non-Hodgkins lymphoma is correlated with clinical features and the presence of a unique chromosomal abnormality; $\mathrm{t}(2: 5)$ (p23; $\mathrm{q} 35)$. Am f Surg mosomal abnormality; t(2:5)(p23; 35$)$. Am $\mathcal{F}$ Surg
Pathol 1990;14:305-16.

3 Rimokh R, Madaud JP, Berger F, Samarut J, Coiffer B, Germain $\mathrm{D}$, et al. A translocation involving a specific
breakpoint (q35) on chromosome 5 is characteristic of breakpoint (q35) on chromosome 5 is characteristic of
anaplastic large cell lymphoma (Ki-1 lymphoma). $B r f$ Haematol 1989;71:31-6.

24 Patsouris E, Noel H, Lennert K. Histological and immunohistochemical findings in lymphoepithelioid cell lymphoma (Lennert's lymphoma). Am f Surg Pathol 1988;12:341-50.

25 Suchi T, Lennert K, Kikuchi M, Sato E, Stansfeld AG, Feller AC. Histopathology and immunohistochemistry of peripheral T-cell lymphomas: a proposal for their of peripheral T-cell lymphomas: a proposal

26 Slack DN, McCarthy KP, Wiedemann LM, Sloane IP. Slack DN, McCarthy KP, Wiedemann LM, Sloane JP.
Evaluation of sensitivity, specificity and reproducibility of an optimized method for detecting clonal rearrangements of immunoglobulin and T-cell receptor genes in formalin-fixed, paraffin-embedded sections. Diagn Mol Pathol 1993;2:223-32

27 Pelicci P-G, Knowles DM, Dall-Favera R. Lymphoid tumors displaying rearrangements of both immunoglobulin and $\mathrm{T}$ cell receptor genes. F Exp Med 1985;162: 1015-24. 